\title{
General Circulation in the Malacca Strait and Andaman Sea: A Numerical Model Study
}

\author{
${ }^{1}$ Syamsul Rizal, ${ }^{2}$ Peter Damm, ${ }^{1}$ Mulyadi A. Wahid, ${ }^{2}$ Jurgen Sundermann, \\ ${ }^{1}$ Yopi Ilhamsyah, ${ }^{3}$ Taufiq Iskandar and ${ }^{1}$ Muhammad \\ ${ }^{1}$ Jurusan Ilmu Kelautan, Universitas Syiah Kuala, Darussalam, Banda Aceh 23111, Indonesia \\ ${ }^{2}$ Institut fur Meereskunde, Universität Hamburg, Bundesstr. 53, 20146 Hamburg, Germany \\ ${ }^{3}$ Jurusan Matematika, Universitas Syiah Kuala, Darussalam, Banda Aceh 23111, Indonesia
}

Received 2012-05-10, Revised 2012-08-11; Accepted 2012-08-11

\begin{abstract}
In the Andaman Sea and Malacca Strait, as in other parts of the Indian Ocean, the seasonal change of the wind plays a most important role: the south-west (hereafter SW) is monsoon active from June through September and the north-east (hereafter NE) monsoon is active from December through February. During the NE monsoon the winds are directed from the north and northeast to the south-west, and during the SW monsoon from the south-west to the north-east. Strong winds between June and September lead to maximum rainfall over most parts of the Indian subcontinent. These areas are also greatly influenced by the tides. The circulation in the Andaman Sea and the Malacca Strait is simulated with a three-dimensional baroclinic primitive equation model. In order to run the model, the HAMSOM model is used. The model is forced by tides at the open boundaries as well as by wind and heat flux. We use also the NCEP/NCAR data. The M2-tide amplitudes are bigger in the shallow areas in the northwest part coast of Andaman Sea and in the Malacca Strait. The phases of M2 tide shows that the M2 tidal wave come from Indian Ocean and bifurcates to the Andaman Sea and Malacca Strait. The current ellipses of M2-tide are also stronger in the shallow areas both in the Andaman Sea and Malacca Strait. There are two types of tidal distribution in the Andaman Sea and Malacca Strait. In the Indian Ocean part and in the middle of the Malacca Strait, the type is mixed tide prevailing semi diurnal, while in the Andaman Sea and the southern part of the Malacca Strait the type is semi diurnal tide. Generally, the general circulation caused by tides, heat flux and wind both for NE and SW monsoon shows the same pattern. These general circulation patterns, vertical structure of temperature and salinity in the Malacca Strait are compared with the observations carried out by other researchers. Based on those comparisons, the results of the model are reasonable. It means, the HAMSOM model can be used for the simulation of the Andaman Sea and Malacca Strait.
\end{abstract}

Keywords: Tides, Sea Surface Temperature, Seasonal Circulation, Three-Dimensional Model, Malacca Strait, Andaman Sea

\section{INTRODUCTION}

The Andaman Sea is located along the northeastern side of the Indian Ocean between the Malay Peninsula to the east and the Andaman-Nicobar islands chain to the west. It can be considered, to a certain extent, as a separate sea. The Andaman and Nicobar islands on the western side of the Andaman Sea are volcanic in origin. As a result the water depth

in this region changes rapidly from over 3000-4000 meters in the Indian Ocean to approximately 200 meters in the area around the islands, returning to deeper than 2500 meters in the centre of the Andaman Sea (Fig. 1).

In the Andaman Sea, the internal wave is commonly observed. Internal waves occur within subsurface layers of marine waters that are stratified because of temperature and salinity variations. Disturbances created Corresponding Author: Syamsul Rizal, Jurusan Ilmu Kelautan, Universitas Syiah Kuala, Darussalam, Banda Aceh 23111, Indonesia 
within the ocean give rise to these waves, which represent a significant mechanism for the transport of momentum and energy within the ocean. Disturbances are often caused by tidal flow passing over shallow underwater obstacles such as a sill or a shallow ridge (Osborne and Burch, 1980; Susanto et al., 2005).

The Malacca Strait is located between the east coast of Sumatra and the west coast of the Malay Peninsula. Its southern most part is connected to the Sunda Shelf, i.e., the southern part of the South China Sea and the western Java Sea are adjacent waters. Water depth changes slightly from approximately $30 \mathrm{~m}$ in the south to $200 \mathrm{~m}$ at the line Lhokseumawe (Indonesia)-Phuket (Thailand). The shelf edge is located to the north of this borderline and the water depth increases to more than $1000 \mathrm{~m}$ in the transition region to the Andaman Sea (Fig. 1).

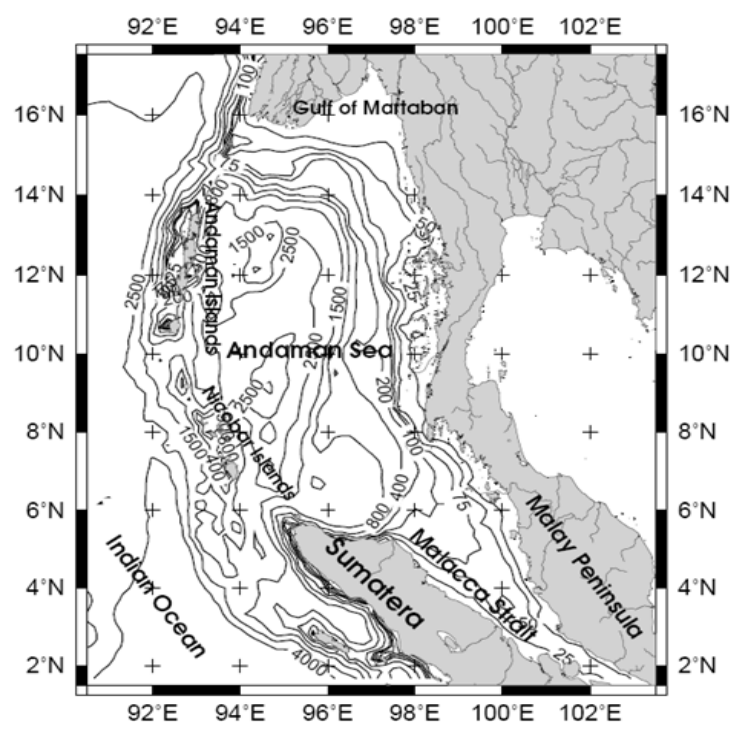

Fig. 1. The topography of Andaman Sea and Malacca Strait, depths are given in meters

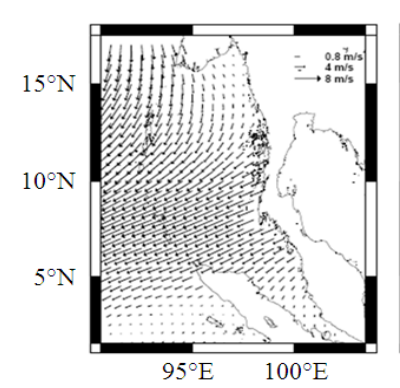

(a)

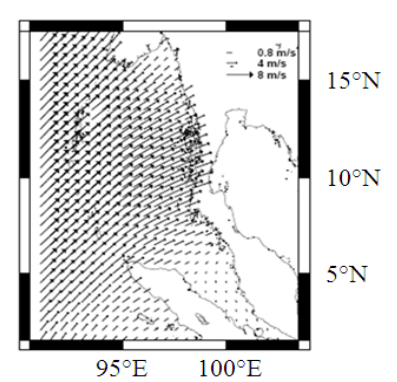

(b)
Fig. 2. Wind field during (a) Northeast monsoon season and (b) Southwest monsoon season
In the Andaman Sea and Malacca Strait, as in other parts of the Indian Ocean, the seasonal change of the wind plays a most important role: the south-west (hereafter SW) is monsoon active from June through September and the north-east (hereafter NE) monsoon is active from December through February.

Figure 2 shows the NE and SW monsoon conditions in the Andaman Sea, derived from long-term (19852003) averages of NCEP/NCAR reanalysis data. During the NE monsoon the winds are directed from the north and northeast to the south-west, and during the SW monsoon from the south-west to the north-east. Strong winds between June and September lead to maximum rainfall over most parts of the Indian subcontinent.

This background, together with the complex topography, makes the Andaman Sea and also the Malacca Strait a great challenge for hydrodynamicnumerical modelling. The Andaman Sea and the Malacca Strait are relatively poorly studied and available data for these areas are sparse.

The objective of this investigation is to study the hydrodynamics of the Andaman Sea and Malacca Strait, with a high resolution simulation of the baroclinic circulation using the HAMburg Shelf Ocean Model (HAMSOM). The M2-tide amplitudes, phases, M2-tidal ellipses and tidal type are presented. The surface circulation pattern, sea surface salinity and sea surface temperature are analysed and compared with other results. In order to validate the model results, the vertical structure of salinity and temperature in the Malacca Strait obtained by HAMSOM are also compared with the observation carried out by Keller and Richards (1967).

\section{MATERIALS AND METHODS}

The model covers the region $90.5 \mathrm{E}$ to $103.5 \mathrm{E}$ and $1.5 \mathrm{~N}$ to $17.5 \mathrm{~N}$ (Fig. 1). In this investigation, the model area is discretized with a horizontal mesh size of $\Delta x=\Delta y$ $=10$ angular minutes. In the vertical direction, the model has 19 layers, i.e., $0-10,10-20,20-30,30-50,50-75,75-$ $100,100-125,125-150,150-200,200-250,250-300,300-$ $400,400-600,600-800,800-1000,1000-1500,1500-$ 2000, 2000-4000, and greater than $4000 \mathrm{~m}$.

The time-step is $\Delta \mathrm{t}=300 \mathrm{~s}$. At the open boundaries, amplitudes and phases of the five major tidal constituents (M2, S2, N2, K1, O1) are prescribed from a global tidal model (Zahel et al., 2000) and T, S from the climatological data of Levitus (1982). The atmospheric forcing, i.e. winds and surface heat fluxes are derived from the NCEP/NCAR reanalysis data (Kalnay et al., 1996).

In order to run the model, we use the HAMSOM Model. HAMSOM is a three-dimensional baroclinic primitive equation model. The underlying differential 
equations are as follows, x-component momentum equation:

$$
\begin{aligned}
& \frac{\partial u}{\partial t}+u \frac{\partial u}{\partial x}+v \frac{\partial u}{\partial y}+w \frac{\partial u}{\partial z}-f v= \\
& -\frac{1}{\rho} \frac{\partial p}{\partial x}+A_{H} \nabla^{2} u+\frac{\partial}{\partial z}\left(A_{v} \frac{\partial u}{\partial z}\right)+F_{x}
\end{aligned}
$$

y-component momentum equation:

$$
\begin{aligned}
& \frac{\partial v}{\partial t}+u \frac{\partial v}{\partial x}+v \frac{\partial v}{\partial y}+w \frac{\partial v}{\partial z}+f u= \\
& -\frac{1}{\rho} \frac{\partial p}{\partial y}+A_{H} \nabla^{2} u+\frac{\partial}{\partial z}\left(A_{v} \frac{\partial v}{\partial z}\right)+F_{y}
\end{aligned}
$$

The variables are three components of the velocity $\mathrm{u}, \mathrm{v}$, and $\mathrm{w}$, pressure $\mathrm{p}$, density $\rho$, three space variables, i.e., $x$ (positive in the east direction), y (positive in the north direction), $\mathrm{z}$ (positive upwards), time $\mathrm{t}$, and Coriolis acceleration $f$. The variables $A_{H}$ and $A_{v}$ are the horizontal and vertical coefficients of turbulent viscosity, respectively, while $F_{X}$ and $F_{Y}$ are the components of the horizontal exterior forces.

Continuity equation:

$$
\frac{\partial u}{\partial x}+\frac{\partial v}{\partial y}+\frac{\partial w}{\partial z}=0
$$

Hydrostatic equation:

$$
\frac{\partial \mathrm{p}}{\partial \mathrm{z}}=-\rho \mathrm{g}
$$

where $\mathrm{g}$ is the gravity acceleration.

Heat transport equation:

$$
\begin{aligned}
& \frac{\partial \mathrm{T}}{\partial \mathrm{t}}+\mathrm{u} \frac{\partial \mathrm{T}}{\partial \mathrm{x}}+\mathrm{v} \frac{\partial \mathrm{T}}{\partial \mathrm{y}}+\mathrm{w} \frac{\partial \mathrm{T}}{\partial \mathrm{z}}= \\
& \mathrm{K}_{\mathrm{H}}^{\mathrm{T}} \nabla^{2} \mathrm{~T}+\frac{\partial}{\partial \mathrm{z}}\left(\mathrm{K}_{\mathrm{v}}^{\mathrm{T}} \frac{\partial \mathrm{T}}{\partial \mathrm{z}}\right)+\mathrm{S}_{\mathrm{T}}
\end{aligned}
$$

and salt transport equation:

$$
\begin{aligned}
& \frac{\partial \mathrm{S}}{\partial \mathrm{t}}+\mathrm{u} \frac{\partial \mathrm{S}}{\partial \mathrm{x}}+\mathrm{v} \frac{\partial \mathrm{S}}{\partial \mathrm{y}}+\mathrm{w} \frac{\partial \mathrm{S}}{\partial \mathrm{z}}= \\
& \mathrm{K}_{\mathrm{H}}^{\mathrm{S}} \nabla^{2} \mathrm{~S}+\frac{\partial}{\partial \mathrm{z}}\left(\mathrm{K}_{\mathrm{v}}^{\mathrm{S}} \frac{\partial \mathrm{S}}{\partial \mathrm{z}}\right)+\mathrm{S}_{\mathrm{S}}
\end{aligned}
$$

where:

$$
\begin{aligned}
& \mathrm{K}_{\mathrm{H}} \text { and } \mathrm{K}_{\mathrm{V}}= \text { The horizontal and vertical coefficients of } \\
& \text { turbulent diffusion, respectively }
\end{aligned}
$$

$\mathrm{S}_{\mathrm{T}}$ and $\mathrm{S}_{\mathrm{S}}=$ Sources of heat and salinity, respectively

At the surface, the kinematic boundary condition is used:

$\frac{\partial \zeta}{\partial \mathrm{t}}=\mathrm{w}$

where $\zeta$ is the water level height.

The differential equations are integrated over the vertical extent of the model layer to arrive at differential equations for the layer-averaged fields of transports (U, $\mathrm{V})$, temperature $\mathrm{T}$ and salinity $\mathrm{S}$. The deduction of the layer averaged equations of motion can be found in Pohlmann (1996). These latter equations are transformed into finite-difference representations on the staggered Arakawa c-grid (Arakawa and Lamb, 1977).

For the discretization of the time domain a two-time level scheme is introduced. The prognostic variables $\zeta$, $\mathrm{U}, \mathrm{V}, \mathrm{T}, \mathrm{S}$ which enter the implicit algorithm, are defined at staggered time-levels. In order to eliminate the stability limitation imposed by the CFL criterion in the hydrodynamic equations, semi-implicit algorithms for sea surface height in the horizontal direction and vertical shear stress in the vertical direction are applied.

In the equations of motion, a stable second-order approximation is introduced to the Coriolis terms, in order to avoid linear numerical instability arising from the forward-in-time approximation (Backhaus, 1985).

\section{RESULTS AND DISCUSSION}

Figure 3 shows the simulated amplitudes and phases of the M2-tide in the model region. In the Malacca Strait, the results agree well with those of Rizal and Sundermann (1994) and Rizal (2000). There is no real amphidromic point in the Malacca Strait and Andaman Sea, because Malacca Strait and Andaman Sea are located in low latitude, see the explanation in Rizal (2002). The M2 amplitudes are large in the areas of shallow continental waters $(<100 \mathrm{~m})$ along the west coast of Myanmar and in the southern part of the Malacca Strait (Fig. 3a). Its waves propagate from the Indian Ocean to the Andaman Sea and bifurcate towards the Gulf of Martaban and the Malacca Strait, indicated by increasing phase change on the shallow shelf (Fig. 3b).

The M2 current ellipses and their contours of semi major corresponding axes at the surface are shown in Fig. 4. Distinct ellipses occur on the shallow shelf in the north-east of the Andaman Sea. There, the orientation of the semi major axes is normal to the coastline, i.e., the strong tidal currents are directed normal to the coastline. 
Syamsul Rizal et al. / American Journal of Environmental Science 8 (5) (2012) 479-488

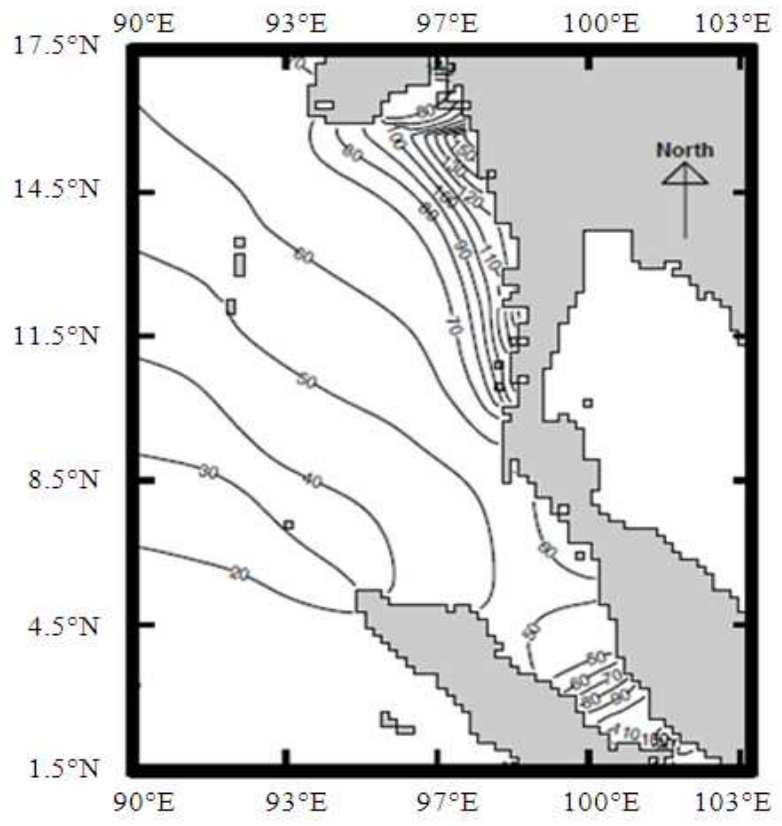

(a)

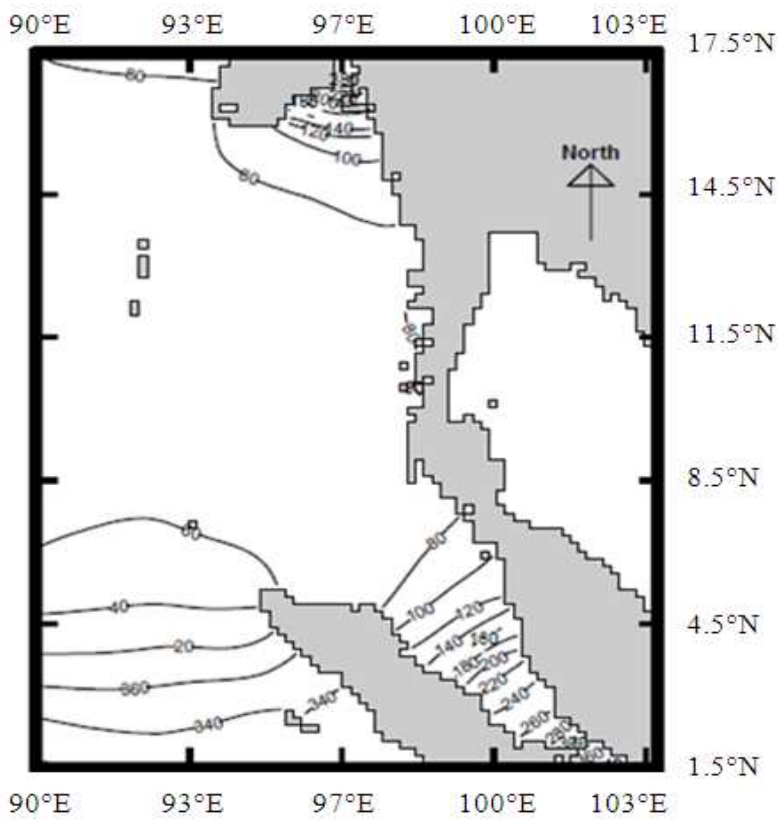

(b)

Fig. 3. The distribution of M2-tide based on HAMSOM (a) Amplitudes in cm, (b) Phases in degree

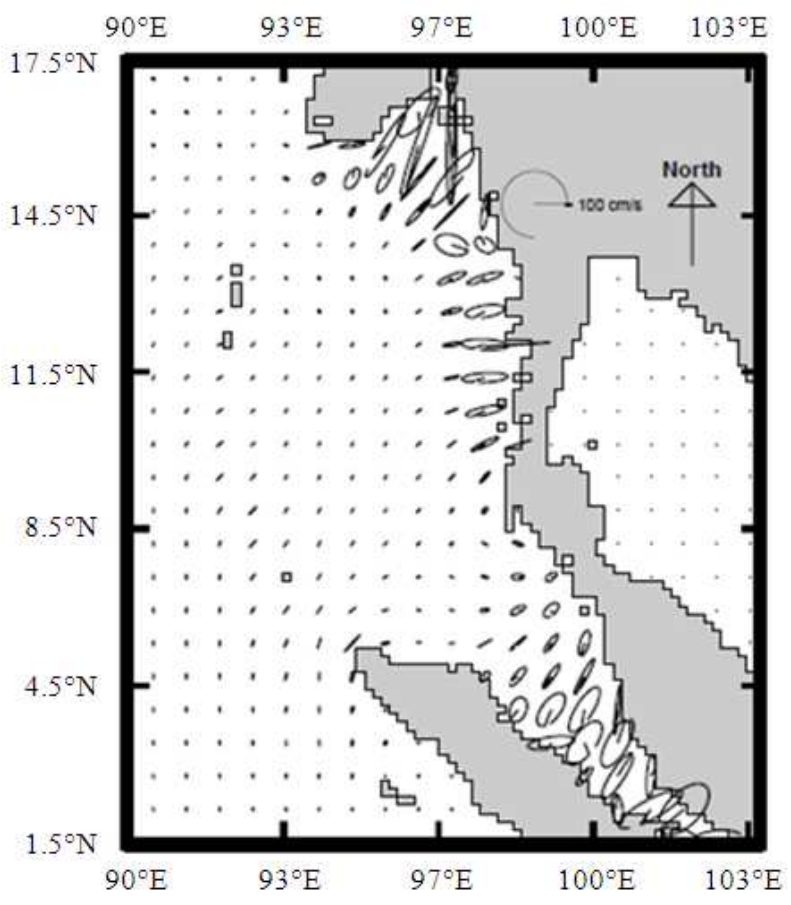

(a)

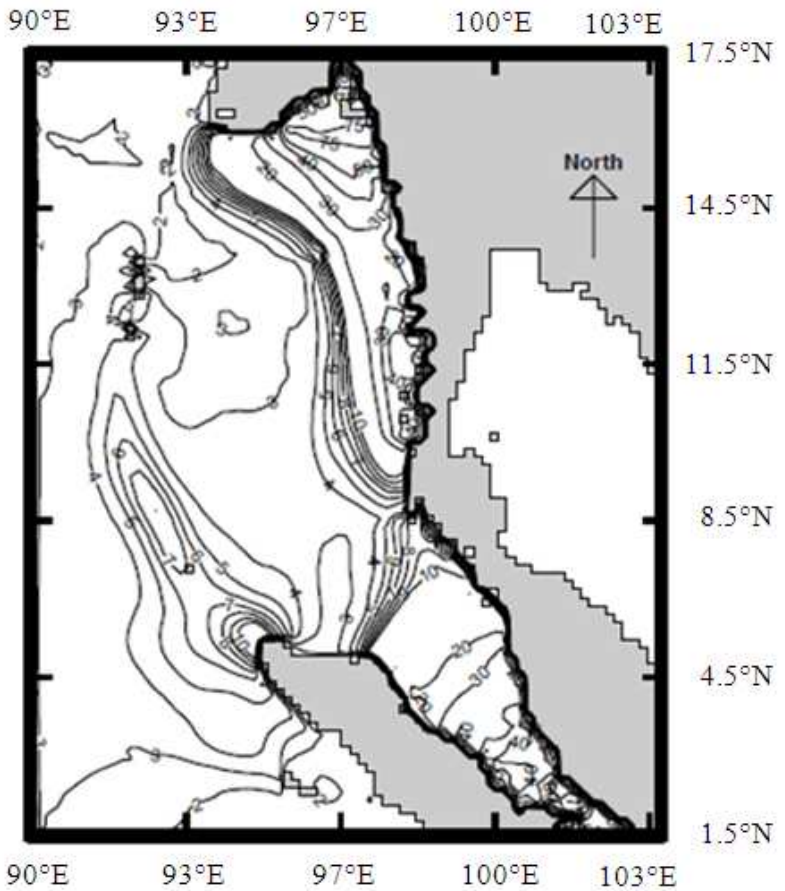

(b)

Fig. 4. (a) Current ellipses of M2-tide in $\mathrm{cm} / \mathrm{s}$ and (b) its Semi Major in $\mathrm{cm} / \mathrm{s}$, both figures based on HAMSOM 
Also considerable M2 current ellipses are seen in the narrow part of the Malacca Strait. The amplitude of these ellipses decreases toward the Andaman Sea. Their major axes are perpendicular to the main axis of the Malacca Strait, and turn slightly north in the north-east corner of the transition zone from the Malacca Strait to the Andaman Sea
(Fig. 4a). The semi major surface currents are weak $(<5$ $\mathrm{cm} / \mathrm{s}$ ) in the deep area of the Andaman Sea and stronger than $10 \mathrm{~cm} / \mathrm{s}$ on the shelf (Fig. $\mathbf{4 b}$ ). The locations of large current gradient contours are due to the shelf edge along the north-east Andaman Sea, the entry to the Malacca Strait and around the shallow off shore area north of Sumatra.

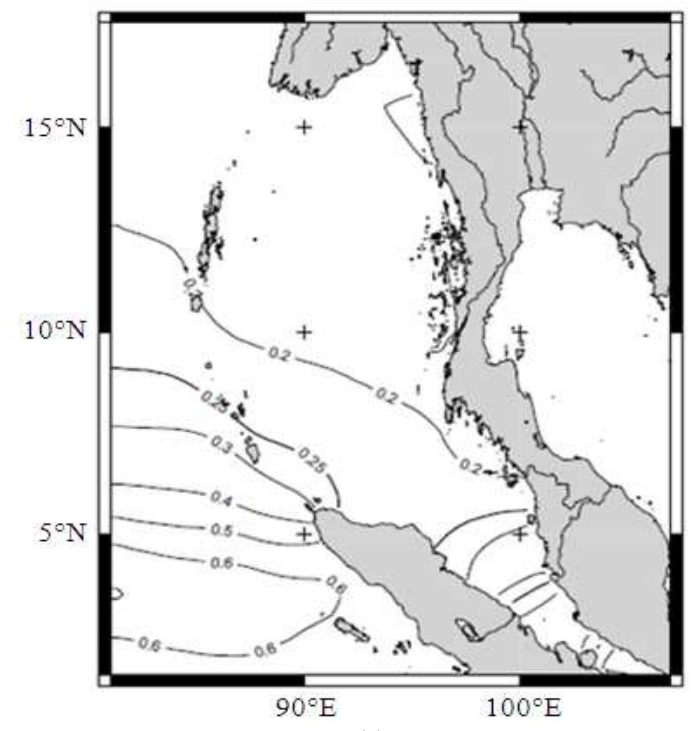

(a)

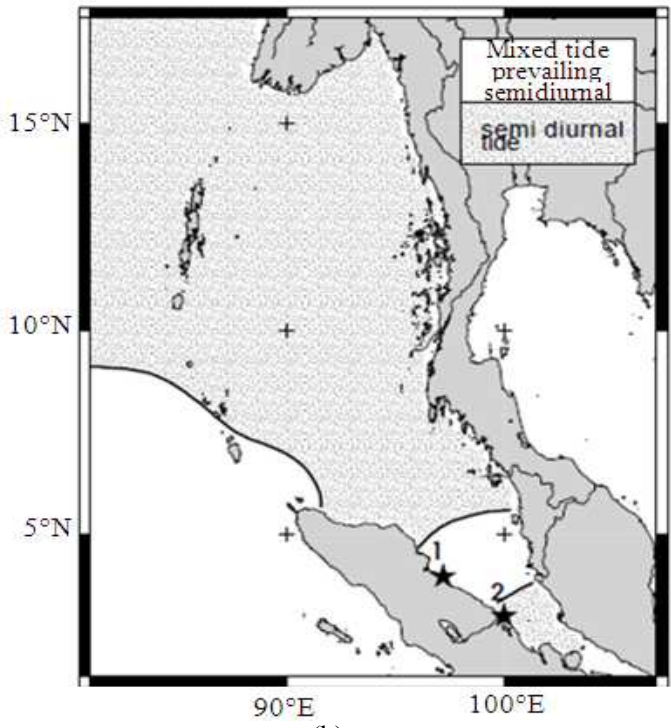

(b)

Fig. 5. Type of tidal distribution in Andaman Sea and Malacca Strait based on HAMSOM, (a) ratio of (K1 + O1)/(M2 + S2), (b) Tidal types distribution

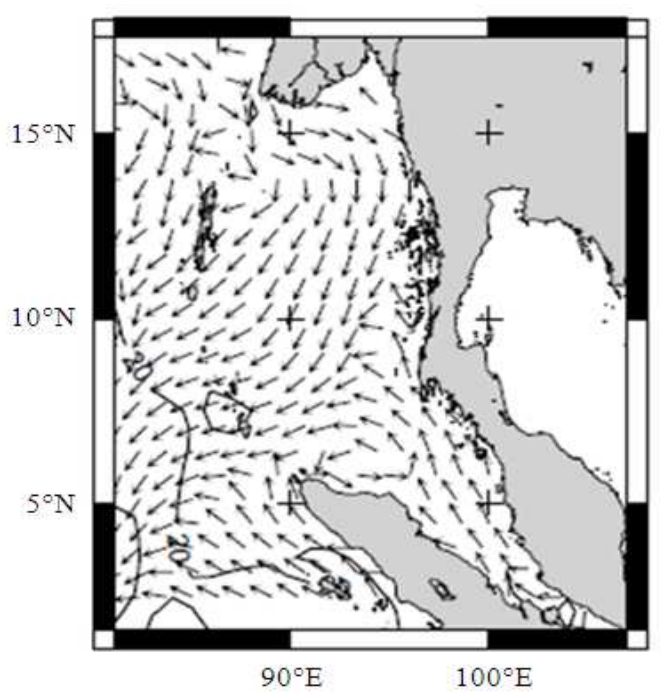

(a)

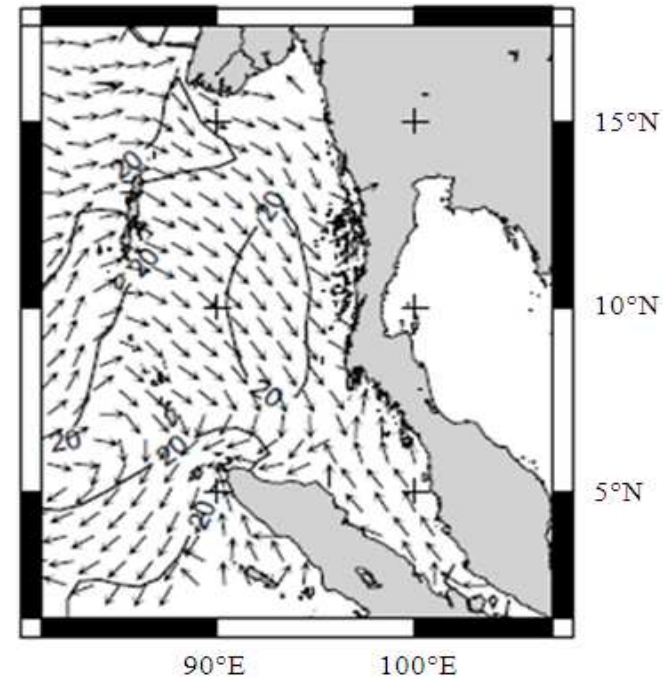

(b)

Fig. 6. The surface currents caused by tides, wind and heat flux derived from long-term (1985-2003) (a) December through February average (NE Monsoon) and (b) June through September average (SW Monsoon) based on HAMSOM. Contour values mean magnitude of velocity in $\mathrm{cm} / \mathrm{s}$ 
The tidal type is defined by the amplitude ratio of the major diurnal to semidiurnal constituents:

$\mathrm{F}=\frac{\mathrm{K}_{1}+\mathrm{O}_{1}}{\mathrm{M}_{2}+\mathrm{S}_{2}}$

Two major types are found in the Andaman Sea as well as in the Malacca Strait, (1) 0 - 0.25: Semidiurnal tide. Two high waters and two low waters daily, of almost equal amplitude, (2) 0.25-1.5: Mixed tide, prevailing semidiurnal. Daily, two high waters and two low waters, but divergent in high and high water time.

The results of the hydrodynamic-numerical simulation with HAMSOM reveal a tidal type of less than 0.25 for the whole Andaman Sea, i.e., semidiurnal tidal conditions with two high and two low waters daily of almost equally high (Fig. 5a and b).

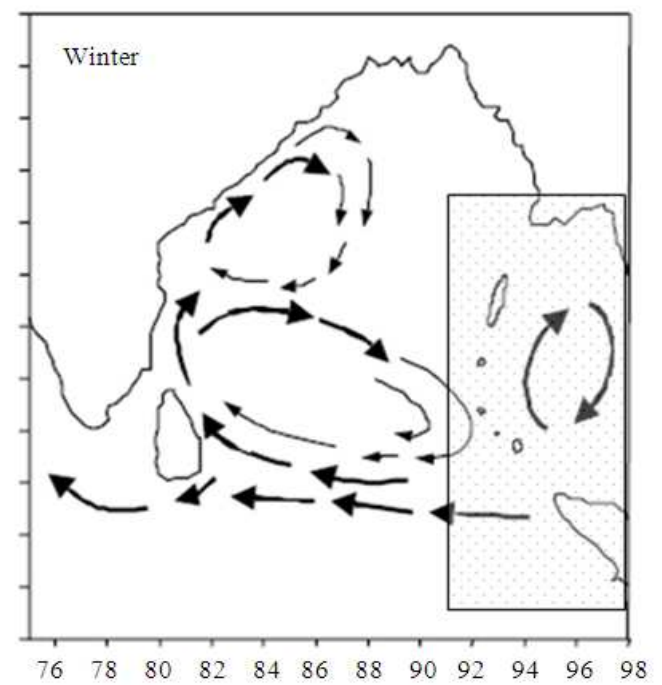

(a)

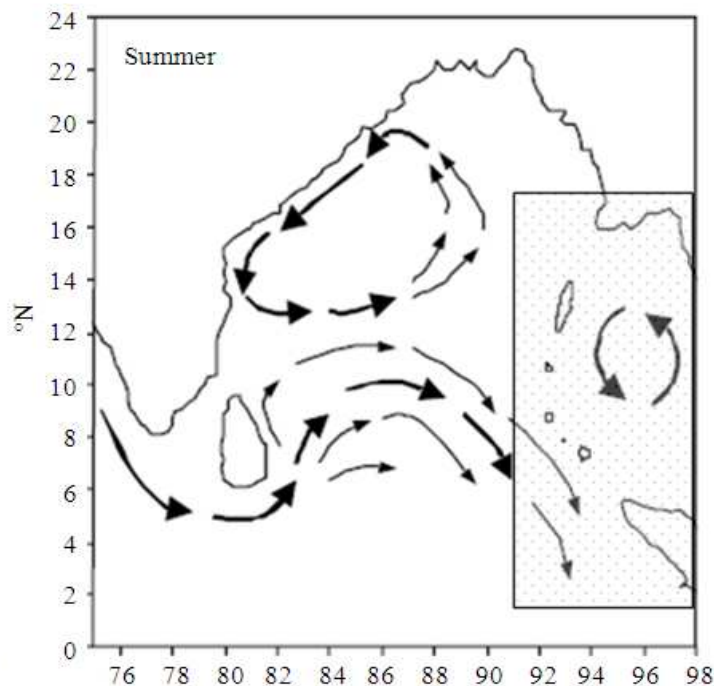

(b)

Fig. 7. Surface circulation pattern in the Bay of Bengal and Andaman Sea during (a) NE monsoon and (b) SW monsoon, reproduced after Varkey et al. (1996)

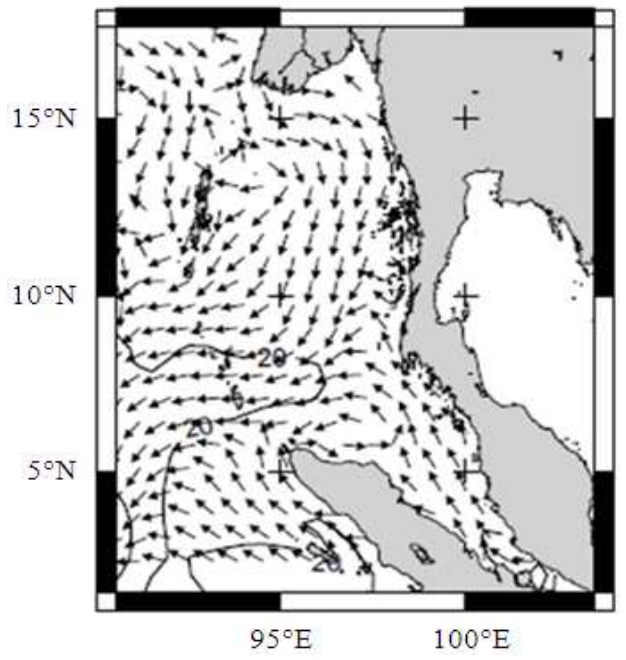

(a)

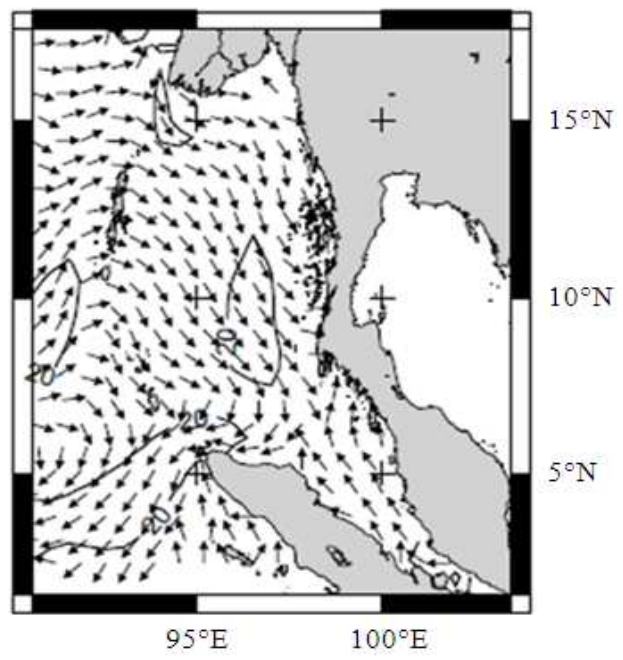

(b)

Fig. 8. The climatology surface currents caused by tides, wind and heat flux derived from long-term (1985-2003) (a) February and (b) August average based on HAMSOM. Contour values mean magnitude of velocity in $\mathrm{cm} / \mathrm{s}$ 
These results agree well with those of Wyrtki (1961) except in the middle of the Malacca Strait, where Wyrtki also observed semidiurnal tides. However, the tidal types in Belawan and Kuala Tanjung (see station 1 and 2 in Fig. 5b) have values 0.27 and 0.42 , respectively, after Dishidros (2002).

Surface currents due to tides, wind and heat flux are shown in Fig. 6. Figure 6a represents the longterm (1985-2003) December through February (NE monsoon) average, and Fig. 6b the long-term (19852003) June through September (SW monsoon) average. During the NE monsoon, surface water masses from the north of domain enter the Andaman Sea. These water masses move to the south and leave the Andaman Sea in the wide area between south of the Andaman Islands and Sumatra to the Indian Ocean. A second surface water masses enter the Andaman Sea from the north-east side of the Malacca Strait. It spreads to the borderline between Thailand and Myanmar. An anticlockwise gyre is located north of Sumatra, in the Malacca Strait. This gyre blocks the outflow of the Malacca Strait over a part of its whole breadth.

During the SW monsoon, the surface water masses in the north enter the Andaman Sea over a long section from Cape Negrais to the north of the Nicobar Islands. The outflow of the Andaman Sea surface water is concentrated between the south of the Nicobar Islands and Sumatra. The local anticlockwise gyre north of Sumatra vanishes. A recirculation regime is generated, with water masses coming from the Andaman Sea

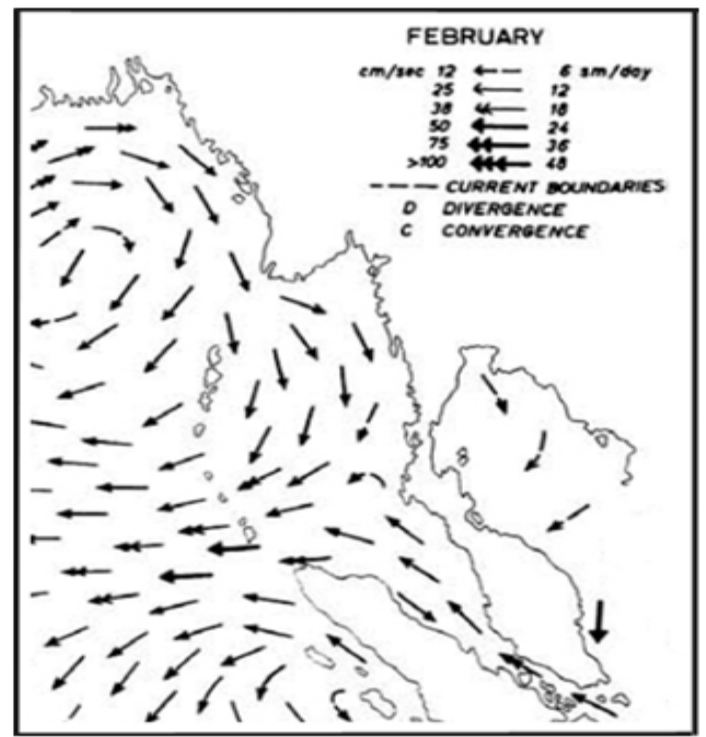

(a) recirculating along the north coast of Sumatra to the Indian Ocean. The second entry of surface water masses into the Andaman Sea still occurs. However, it is closer to the coast of Malay Peninsula and flows towards the island Phuket.

In the Malacca Strait, the surface flow is always directed north-westward towards the Andaman Sea, for both SW and NE monsoon situations, since the sea surface elevation in the south-east domain (South China Sea) is always higher than in the Andaman Sea during both SW and NE monsoons (Wyrtki, 1961). For the NE monsoon, a water mass with high salinity from the South China Sea flows into the Malacca Strait. The SW monsoon drives a water mass with low salinity from the Java Sea into the Malacca Strait.

In general, circulation patterns shown in Fig. 6 are not similar to that of Varkey et al. (1996). They found that there is one main gyre for each season in the centre of the Andaman Sea, i.e. a clockwise gyre during the NE monsoon and an anticlockwise gyre during the SW monsoon, see Fig. 7. However, the investigation of Varkey et al. is mainly focused on the Bay of Bengal.

The climatological surface circulations for the months February and August obtained by averaging over the period 1985-2003 are shown in Fig. 8. These are similar to our results of seasonal circulation patterns and also to the work of Wyrtki (1961). In particular, in his report no gyre in the centre of the Andaman Sea is documented (Fig. 9).

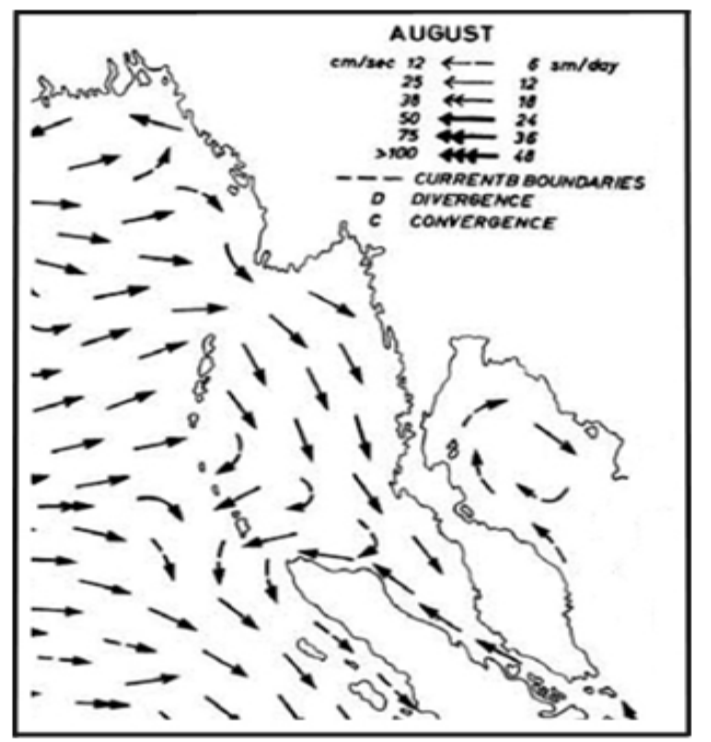

(b)

Fig. 9. Surface currents during (a) February and (b) August, according to Wyrtki (1961) 


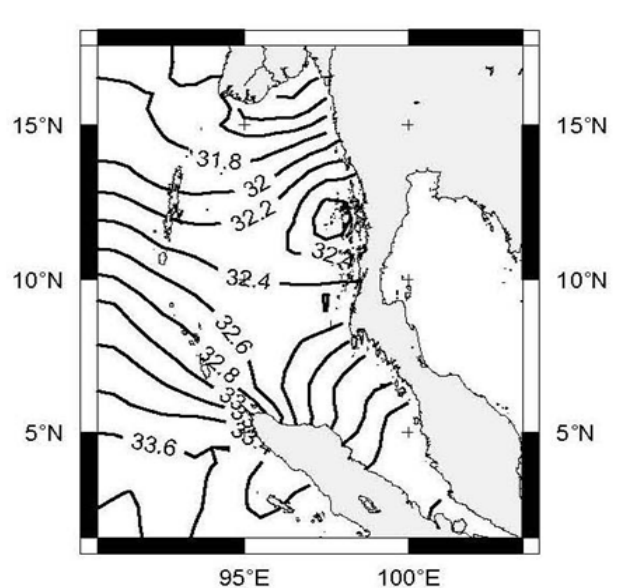

(a)

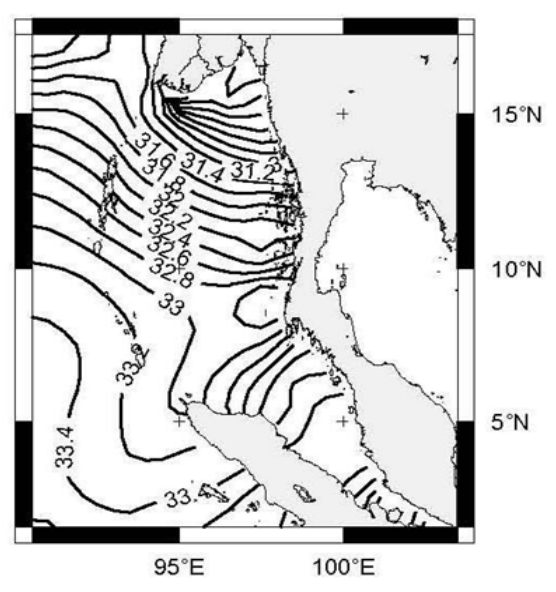

(b)

Fig. 10. SSS based on HAMSOM during (a) NE Monsoon (b) SW Monsoon

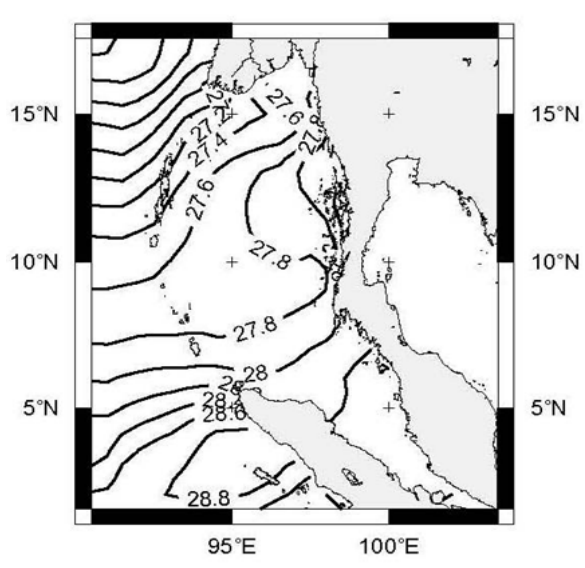

(a)

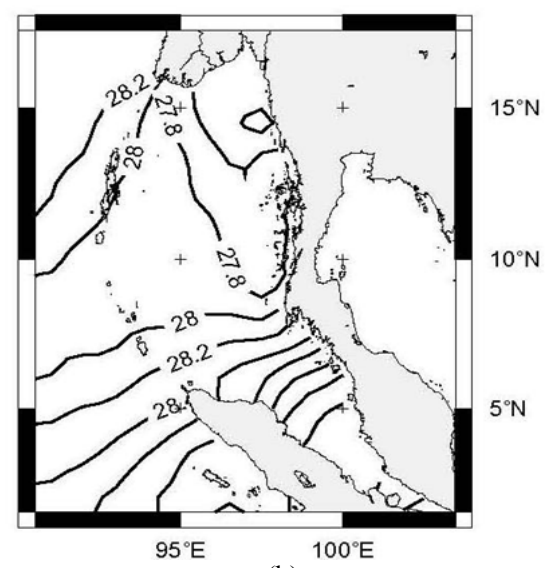

(b)

Fig. 11. SST based on HAMSOM in (a) February (b) August 1996

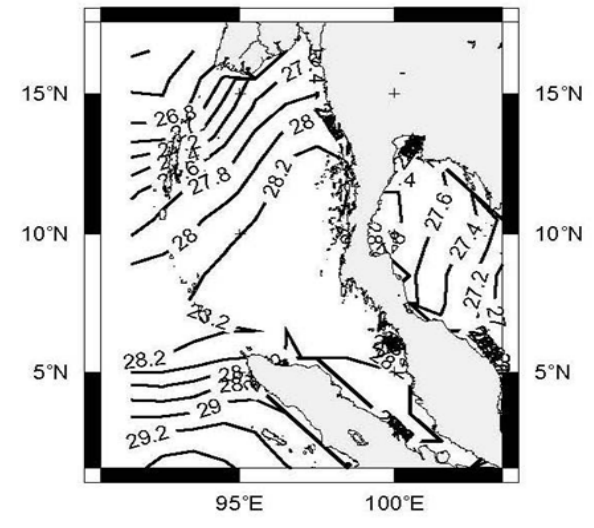

(a)

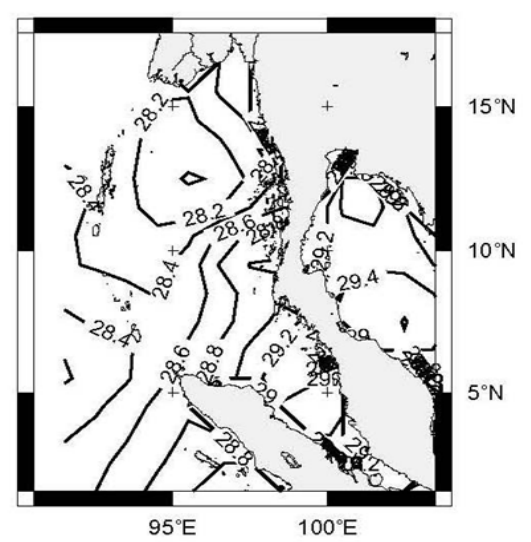

(b)

Fig. 12. SST in (a) February and (b) August 1996 according to UKMO 


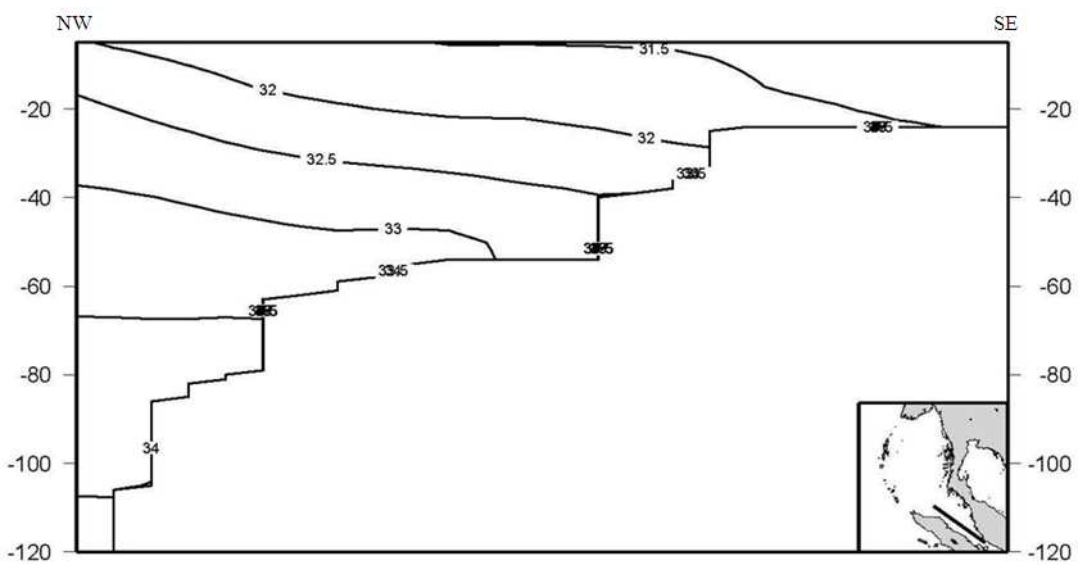

Fig. 13. The salinity cross section in April 1961 in the Malacca Strait as show in inset for the depth of 0-120 m based on HAMSOM

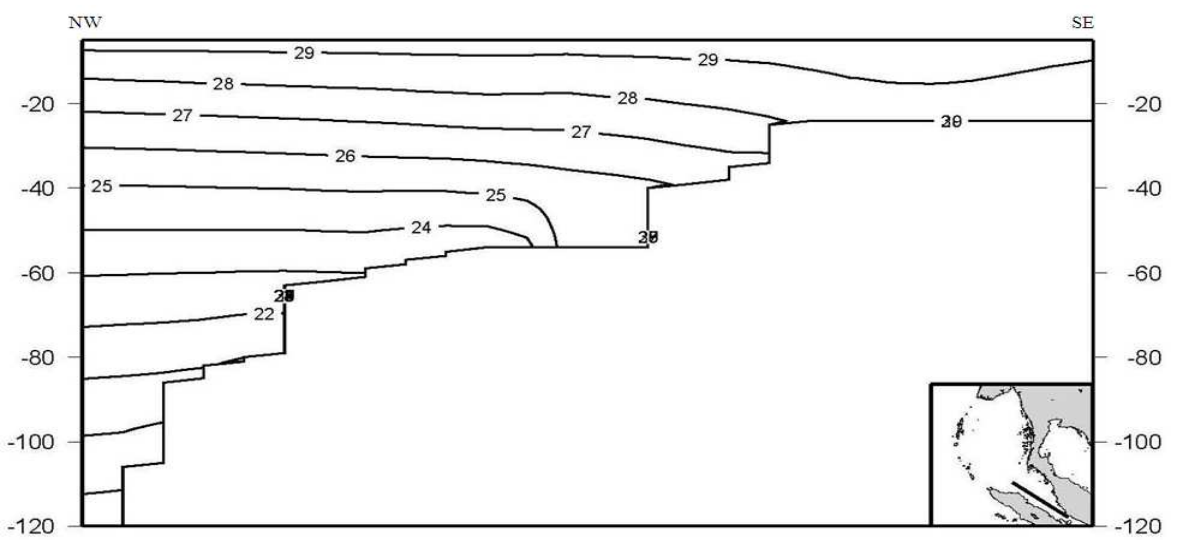

Fig. 14. The temperature cross section in April 1961 in the Malacca Strait as shown in inset for the depth of 0 to $120 \mathrm{~m}$ based on HAMSOM

Sea surface salinity for the NE and SW monsoons obtained by averaging over the period 1985-2003 for the months December through February and June through September, respectively, is shown in Fig. 10. In the Gulf of Martaban and in the south-western part of the Malacca Strait, the sea surface salinity is extremely low during the SW monsoon. As has been stated above, strong winds from the SW lead to maximum rainfall over most parts of the Indian subcontinent from June to September with corresponding maximum river runoff to the Gulf of Martaban, whereas NE monsoon winds during December-February bring heavy rainfall only to southeastern India (Ramage, 1971; Unger et al., 2003). The low salinity in the south-western part of the Malacca Strait is caused by inflow of a water mass from the Java Sea, which is driven by the SW monsoon.

Figure 11 shows simulated SST distributions during February 1996 and August 1996, representing NE and
SW monsoons, respectively. Maximum temperatures for both cases occur in the Malacca Strait and the Indian Ocean near Sumatra Island. The same distribution can be found in Fig. 12 which shows the distribution of SST according to United Kingdom Meteorological Office (UKMO), see

http://badc.nerc.ac.uk/data/hadisst/file format.html\#sst.

Another validation of the model is provided by comparison with observations in April 1961 made by Keller and Richards (1967). Figure 13 and 14 can reproduce the same results as has been observed by Keller and Richards (1967). Figure 13 shows a salinity cross section in April 1961 in the Malacca Strait produced by HAMSOM. It is seen that only in the southeastern part of the Malacca Strait, the salinity is well mixed. In other areas, salinity ranges from 31.5 at the surface and 34.5 at the bottom. This pattern agrees well with that of Keller and Richards (1967). 
Figure 14 shows the same cross section of model results as mentioned above, but now for vertical temperature distribution in April 1961. The temperature pattern also exhibits a vertical gradient with values of $29^{\circ} \mathrm{C}$ at the surface and $19^{\circ} \mathrm{C}$ at the bottom. This pattern is also very similar with the observations in April 1961 which were carried out by Keller and Richards (1967).

\section{CONCLUSION}

From the results described above, it can be concluded that the semidiurnal tides, especially the M2tide, are very dominant in the domain of investigation. The M2 current magnitude is very large northwest part of Andaman Sea and in the Malacca Strait. Surface current distributions in the Andaman Sea and the northern part of the Malacca Strait change seasonally, depending on the two different monsoon situations. The good agreement of the general circulation pattern from Wyrtki (1961) with the simulation results confirms Wyrtki's work. The high resolution of the model reveals more details of the current distribution and therefore a deeper understanding of the current dynamic and its water mass transport is possible. This demonstrates the importance of using hydrodynamic-numerical models for investigations concerning water mass processes in the ocean as well as on the shelf. Salinity and temperature cross sections are in good agreement with those observed by Keller and Richards (1967). There are vertical gradients of salinity and temperature in the Malacca Strait with surface values of 31.5 and $29^{\circ} \mathrm{C}$ for salinity and temperature, respectively and bottom values of 34 and $19^{\circ} \mathrm{C}$.

\section{ACKNOWLEDGEMENT}

The researchers would like to thank Dr. Mutiara R. Putri of Institut Teknologi Bandung, Indonesia, Dagmar Hainbucher, Kieran O'Driscoll, Udo Hubner and Dr. Thomas Pohlmann of Institut fur Meereskunde der Universität Hamburg, Germany, for fruitful discussions. This research is funded by German Federal Ministry of Education and Research (BMBF, IDN 01/007) and Ministry of National Education, Republic of Indonesia (Contract: 096/H11-P2T/A.01/2009/Riset Unggulan Strategi Nasional).

\section{REFERENCES}

Arakawa, A. and V.R. Lamb, 1977. Computational design of the basic dynamical processes of the UCLA general circulation model. Methods Comput. Phys., 17: 173-263.
Backhaus, J.O., 1985. A three-dimensional model for the simulation of shelf sea dynamics. Ocean Dynamics, 38: 165-187. DOI: 10.1007/BF02328975

Dishidros, 2002. Tide tables indonesian archipelago. Dinas Hidro-Oseanografi, Jakarta.

Kalnay, E., M. Kanamitsu, R. Kistler, W. Collins and D. Deaven et al., 1996. The NCEP/NCAR 40 year reanalysis project. Bull. Am. Meteorol. Soc. 77: 437-471.

Keller, G.H. and A.F. Richards, 1967. Sediments of the Malacca Strait, Southeast Asia. J. Sedimentary Res., 37: 102-107. DOI: 10.1306/74D7166D-2B21-11D7$8648000102 \mathrm{C} 1865 \mathrm{D}$

Levitus, S., 1982. Climatological Atlas of the World Ocean. 1st Ed. National Oceanic and Atmospheric Administration, Washington, D.C., pp: 173.

Osborne, A.R. and T.L. Burch, 1980. Internal Solitons in the Andaman Sea. Science, 208: 451-460. DOI: 10.1126/science. 208.4443 .451

Pohlmann, T., 1996. Calculating the development of the thermal vertical stratification in the North Sea with a three-dimensional baroclinic circulation model. Continental Shelf Res., 16: 163-194. DOI: 10.1016/0278-4343(95)00018-V

Ramage, C.S., 1971. Monsoon Meteorology. 1st Ed., Academic Press, New York, pp: 296.

Rizal, S. and J. Sundermann, 1994. On the $\mathrm{M}_{2}$-tide of the Malacca Strait: A numerical investigation. Ocean Dynamics, 46: 61-80. DOI: 10.1007/BF02225741

Rizal, S., 2000. The role of non-linear terms in the shallow water equation with the application in threedimensional tidal model of the Malacca Strait and Taylor's Problem in low geographical latitude. Continental Shelf Res., 20: 1965-1991. DOI: 10.1016/S0278-4343(00)00059-5

Rizal, S., 2002. Taylor's problem-influences on the spatial distribution of real and virtual amphidromes, Continental Shelf Res., 22: 2147-2158. DOI: 10.1016/S0278-4343(02)00068-7

Susanto, R.D., L. Mitnik and Q. Zheng, 2005. Ocean Internal waves observed in the Lombok Strait. Oceanography, 18: 80-87.

Unger, D., V. Ittekkot, P. Schafer, J. Tiemann and K. Reschke, 2003. Seasonality and interannual variability of particle fluxes to the deep Bay of Bengal: Influence of riverine input and oceanographic processes. Deep Sea Res. Part II: Topical Stud. Oceanography, 50: 879-923. DOI: 10.1016/S0967-0645(02)00612-4

Varkey, M.J., V.S.N. Murty and A. Suryanarayana, 1996. Physical oceanography of the Bay of Bengal and Andaman Sea. Oceanography Marine Biol.: Annual Rev., 34: 1-70.

Wyrtki, K., 1961. Physical oceanography of the Southeast Asian waters. 1st Ed. University of California, California, pp: 195.

Zahel, W., J.H. Gavino and U. Seiler, 2000. Angular momentum and energy budget of a global ocean tide model with data assimilation. GEOS, 20: 400-413. 